\title{
Transforming growth factor $\beta$ in normal human lung: preferential location in bronchial epithelial cells
}

\author{
Antoine Magnan, Irène Frachon, Bernadette Rain, Michel Peuchmaur, \\ Gianpaola Monti, Bernard Lenot, Michèle Fattal, Gérald Simonneau, \\ Pierre Galanaud, Dominique Emilie
}

INSERM U 131,

Clamart

A Magnan

G Monti

P Galanaud

D Emilie

Centre Chirurgical Marie Lannelongue, Le Plessis-Robinson I Frachon

B Lenot

M Fattal

Service d'Anatomie Pathologique, Hôpital A Béclère, Clamart B Rain

Service d'Anatomie Pathologique, Hôpital R Debré, Paris

M Peuchmaur

Service de

Pneumologie, Hôpital A Béclère, Clamart,

France

G Simonneau

Reprint requests to: Dr Dominique Emilie, INSERM U 131,

32 rue des Carnets, 92140 Clamart, France.

Received 14 October 1993 Returned to authors 16 February 1994 Revised version received 6 April 1994 Accepted for publication 28 April 1994

\begin{abstract}
Background - Transforming growth factor $\beta$ (TGF- $\beta$ ) is an immunomodulatory cytokine regulating the proliferation and differentiation of various cell types. It also contributes to the maintenance of tissue architecture by influencing the production of extracellular matrix components. TGF- $\beta$ has been detected in bronchoalveolar lavage fluid from normal human lung, but the nature and distribution of cells containing TGF- $\beta$ in this organ remain unknown.
\end{abstract}

Methods - Fourteen normal human lung specimens were studied by immunohistochemistry with a monoclonal antibody recognizing TGF $-\beta_{1}$, TGF $-\beta_{2}$ and TGF- $\beta_{3}$.

Results - TGF- $\beta$ was detected in all cases. Bronchial epithelial cells contained the largest amounts of TGF- $\beta$. In these cells the staining was brightest at the apical pole. Macrophages and smooth muscle cells also contained TGF- $\beta$, although less than epithelial cells. No TGF- $\beta$ was detected in other cell populations, including endothelial cells, fibroblasts, and pneumocytes.

Conclusions - The bronchial epithelial compartment appears to be the main location of TGF- $\beta$ in the normal human lung, suggesting that this cytokine has a pivotal role in the immunological properties of the bronchial mucosa.

(Thorax 1994;49:789-792)

Disruption of the TGF- $\beta_{1}$ gene in mice results in an extensive infiltrate of lymphocytes and plasma cells in various organs including the lungs, leading to tissue necrosis and death of the animals. This suggests that transforming growth factor $\beta$ (TGF- $\beta$ ) plays a critical role in situ in lung homeostasis. ${ }^{12}$ Although TGF- $\beta$ has been detected in the bronchoalveolar lavage fluid of normal human individuals ${ }^{3}$ the location of this cytokine has not yet been demonstrated in normal human lung, nor has the nature of the cells containing TGF- $\beta$ been established. As alveolar macrophages can synthesise TGF- $\beta$ in vitro $^{45}$ it has been suggested that this cell population is the main source of TGF- $\beta$ in airways. A number of other cell types are potential producers of TGF- $\beta$, however, including lymphocytes, monocytes, macrophages, neutrophil and eosinophil polymorphonuclear cells, epithelial cells, and mesenchymal cells. ${ }^{6-9}$ In animals the in vivo production of TGF- $\beta$ by bronchial epithelial cells and by smooth muscle cells has been documented. ${ }^{8-12}$

To demonstrate TGF- $\beta$ expression in normal human lung and to address the question of the relative involvement of these different cell populations, the presence of cells containing TGF- $\beta$ and their distribution in normal human lung was analysed by immunohistochemistry.

\section{Methods \\ TISSUES}

A sample of normal human lung tissue was taken during thoracic surgery from 14 individuals ranging in age from 31 to 76 (mean (SD) 57 (4)) years. Nine patients had a peripheral pulmonary carcinoma. Of the five other patients one underwent surgery for a benign pulmonary tumour, two previously treated with chemotherapy for a single pulmonary metastasis from a breast adenocarcinoma had residual lesions which no longer contained tumour cells, one had a persistent pneumothorax, and one had mediastinal Hodgkin's disease. Patients 1-9 were smokers but none had severe respiratory dysfunction. The study was approved by the institutional review board for human studies (Université Paris-Sud).

In all cases a $1 \mathrm{~cm}^{3}$ biopsy specimen was taken from the affected lung at a distance from the lesion requiring surgery. All biopsy specimens contained bronchioles, vessels, and alveoli, and seven samples contained pleural tissue. All tissues were studied by two pathologists to confirm absence of abnormality. In particular, no malignant cells were present in any sample studied.

Lung biopsy samples were snap frozen in liquid nitrogen, embedded in OCT compound (Miles Inc, Elkart, Indiana, USA), and stored at $-80^{\circ} \mathrm{C} ; 7 \mu \mathrm{m}$ sections were cut at $-20^{\circ} \mathrm{C}$ using a cryostat, fixed with acetone for 10 minutes, and air dried. Sections were stored at $-80^{\circ} \mathrm{C}$ before immunostaining.

\section{IMMUNOHISTOCHEMISTRY}

Sections were air dried and fixed with acetone for 15 minutes. All incubations were processed at room temperature in a humid staining box. After rehydration in phosphate buffer solution (PBS) for 20 minutes non-specific protein staining was blocked with $1.5 \%$ horse serum and $48.5 \%$ human $\mathrm{AB}$ serum for 30 minutes. Sections were then incubated for 30 minutes 
with $0.1 \mathrm{mg} / \mathrm{ml}$ of an $\mathrm{IgG}_{1}$ mouse monoclonal antibody that recognised human $T G F-\beta_{1}$, TGF- $\beta_{2}$, and TGF- $\beta_{3}$ (Genzyme, Cambridge, UK). Control sections were incubated with $0.1 \mathrm{mg} / \mathrm{ml}$ of an irrelevant monoclonal mouse $\mathrm{IgG}_{1}$ (F3525) directed against the envelope protein of the hepatitis $B$ virus. As additional controls, the anti-TGF- $\beta$ antibody was omitted, or sections were incubated with various irrelevant monoclonal antibodies: CD3, CD4, CD8 from Becton-Dickinson (Mountain View, California, USA); CD19, CD49, CD54 from Immunotech (Marseille, France); KiM6 from Behring (Rueil, France). After three five minute rinses in PBS sections were incubated for 30 minutes with biotinylated horse antimouse immunoglobulins (Vector Laboratories, Burlingame, California, USA). The samples were rinsed three times for five minutes in PBS and then incubated for 30 minutes with the avidinbiotin-peroxidase complex (Vectastain ABC, Vector Laboratories). Sections were developed in acetate buffer ( $\mathrm{pH} \mathrm{5 \cdot 2)}$ with 3-amino-9ethyl-carbazole (Sigma Chemical Co, St Louis, Missouri, USA) and $0.002 \%$ hydrogen peroxide, rinsed twice in acetate buffer for five minutes and twice in tap water for five minutes. They were then counterstained with Mayer's haematoxylin and mounted in aqueous medium

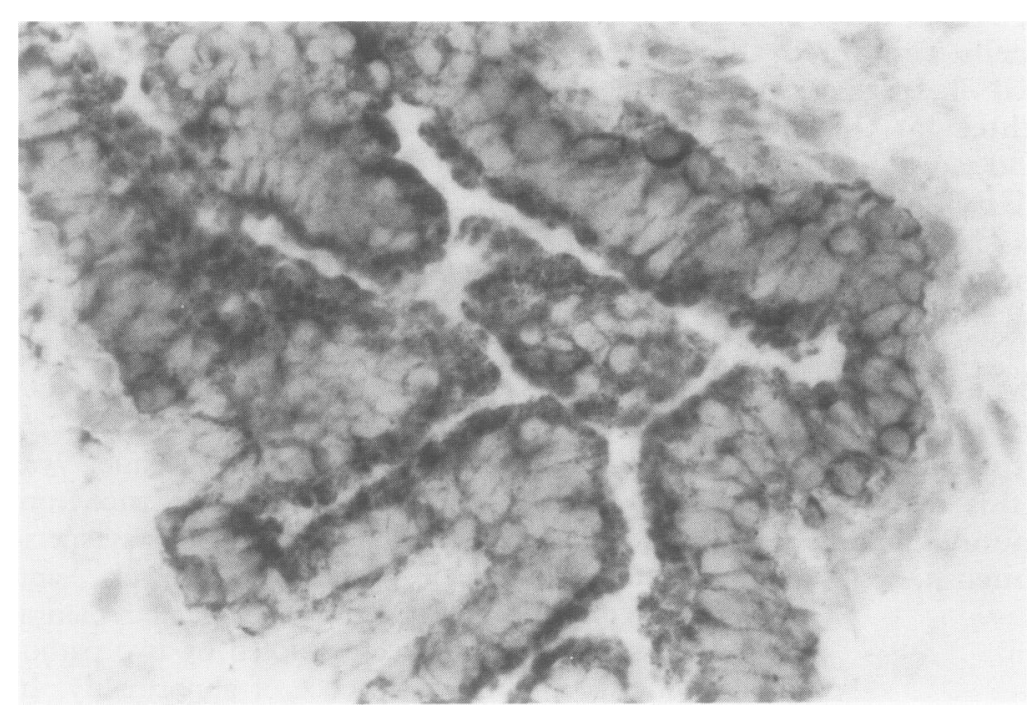

Figure 1 Detection of TGF- $\beta$ in bronchial epithelial cells. Immunohistochemical experiments were performed using an anti-TGF- $\beta$ monoclonal antibody. Results shown are from patient 4 . Original magnification $\times 400$.

Location of cells containing TGF- $\beta$ in normal human lung

\begin{tabular}{|c|c|c|c|c|c|}
\hline Patient & $\begin{array}{l}\text { Bronchial } \\
\text { epithelium }\end{array}$ & $\begin{array}{l}\text { Bronchial } \\
\text { smooth muscle }\end{array}$ & $\begin{array}{l}\text { Vascular } \\
\text { smooth muscle }\end{array}$ & $\begin{array}{l}\text { Alveolar } \\
\text { epithelium }\end{array}$ & Pleura \\
\hline 1 & + & + & + & - & NP* \\
\hline 2 & + & \pm & \pm & - & NP \\
\hline 3 & + & \pm & \pm & - & - \\
\hline 4 & ++ & + & \pm & - & - \\
\hline 5 & ++ & + & + & - & NP \\
\hline 6 & ++ & \pm & \pm & - & NP \\
\hline 7 & ++ & + & + & - & - \\
\hline 8 & + & + & + & - & - \\
\hline 9 & + & \pm & \pm & - & NP \\
\hline 10 & +++ & ++ & \pm & - & - \\
\hline 11 & +++ & ++ & + & - & - \\
\hline 12 & ++ & + & \pm & - & - \\
\hline 13 & ++ & \pm & \pm & - & NP \\
\hline 14 & ++ & + & + & - & NP \\
\hline
\end{tabular}

$-=$ absence of staining; \pm to $+++=$ increasing intensity of staining.

$*$ Not present in the tissue section. in Glycergel (Dakopatts, Copenhagen, Denmark). Several fields in each section were studied through an Olympus microscope by two medical doctors blinded as to the identity of the tissues being studied. The intensity of staining was graded from negative (-) to very intense $(+++)$.

\section{Results}

DETECTION OF TGF- $\beta$ IN NORMAL HUMAN LUNG The presence of TGF- $\beta$ in normal lung was assessed by immunohistochemistry with an anti-TGF- $\beta$ monoclonal antibody in biopsies from 14 subjects undergoing thoracic surgery. The monoclonal antibody used recognised the three isoforms of TGF- $\beta$ : TGF- $\beta_{1}$, TGF- $\beta_{2}$, and TGF- $\beta_{3}$. TGF- $\beta$ was detected in each of the 14 samples, which all displayed a similar pattern (fig 1). Of the five different lung compartments (bronchi, alveoli, interstitium, vessels, and pleura), the bronchial compartment was the most brightly stained (table).

Several controls demonstrated the specificity of the staining observed with the anti-TGF- $\beta$ monoclonal antibody. No labelling was observed when the anti-TGF- $\beta$ monoclonal antibody was omitted from the immunochemical protocol, or when a monoclonal antibody of the same isotype recognising an irrelevant protein was used in place of anti-TGF- $\beta$. Moreover, the pattern of staining obtained when using several other monoclonal antibodies (CD3, CD4, CD8, CD19, CD49, CD54, KiM6) was clearly distinct from that observed with the anti-TGF- $\beta$ monoclonal antibody.

\section{CELLS CONTAINING TGF- $\beta$ WITHIN BRONCHI}

The characteristics of bronchial cells stained with the anti-TGF- $\beta$ were then analysed in more detail. Of the various structures constituting the bronchi, epithelial cells contained the largest amounts of TGF- $\beta$. Indeed, every ciliary epithelial cell was brightly stained with the monoclonal antibody. Although the whole ciliary epithelial cell was stained with the antibody, the signal was always more intense at the apical pole of the cell (fig 1). As the biopsy samples obtained did not include large bronchi, production of TGF- $\beta$ by mucosal epithelial cells could not be determined. Smooth muscle cells also contained TGF- $\beta$. In this case the staining was cytoplasmic and homogeneously distributed within the cell. The intensity was, however, lower than that of epithelial cells.

The submucosal connective tissue did not contain TGF- $\beta$.

\section{DETECTION OF TGF- $\beta$ IN OTHER LUNG} COMPARTMENTS

Outside the airways the anti-TGF- $\beta$ monoclonal antibody labelled a number of cell populations, but the intensity of the staining was in all cases lower than that observed in bronchi.

In vessels, smooth muscle cells were weakly stained by the anti-TGF- $\beta$ monoclonal antibody, whereas endothelial cells and adventitial fibroblasts were not. 


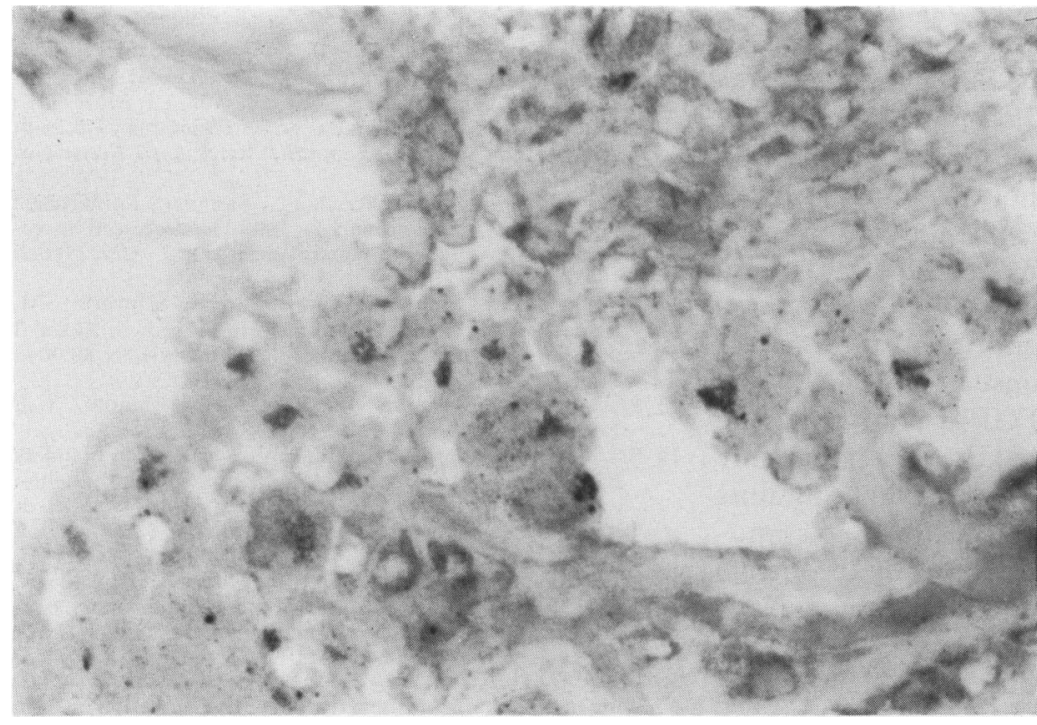

Figure 2 Detection of TGF- $\beta$ in macrophages. TGF- $\beta$ in macrophages was detected using the anti-TGF- $\beta$ monoclonal antibody. Results shown are from patient 1 . Note the location of TGF- $\beta$ in the Golgi apparatus of macrophages. Original magnification $\times 400$.
Nevertheless this staining could also account for TGF- $\beta$ being attached to its receptor on the surface of potential target cells such as epithelial cells, and further experiments using either in situ hybridisation or in vitro production analysis by highly purified epithelial cells are necessary to formally demonstrate an intraepithelial synthesis. Whether the intensity of staining with the anti-TGF- $\beta$ monoclonal antibody differs between smokers and non-smokers is not clear from our study, and further investigations on larger numbers of subjects are required to address this point.

Previous studies have suggested that alveolar macrophages are responsible for the intrapulmonary synthesis of TGF- $\beta .{ }^{45}$ Our study confirms the presence of TGF- $\beta$ in intrapulmonary macrophages and demonstrates that, in these cells as well as in alveolar macrophages obtained by bronchoalveolar lavage (data not shown), TGF- $\beta$ is located in the Golgi apparatus. This is consistent with synthesis of TGF- $\beta$ by macrophages.

Our results contrast with two previous studies which failed to find TGF- $\beta$ in normal human lung by immunohistochemistry. ${ }^{14}{ }^{15}$ In these studies the antibodies used differed from ours and presumably recognised other epitopes of TGF- $\beta$. Moreover, the antibody used by Broekelmann et $a l^{15}$ was polyclonal and only recognised TGF- $\beta$ bound to the extracellular matrix. In both studies tissues were embedded in paraffin, a procedure which affects epitope recognition by antibodies, whereas in our work tissue sections were frozen.

Production of TGF- $\beta$ by bovine bronchial epithelial cells has been reported, ${ }^{8}$ as well as by smooth muscle cells from bovine pulmonary arteries and from rat arteries. ${ }^{911} 12$ Furthermore, the distribution of the TGF- $\beta$-containing cells seen in normal human lung was highly reminiscent of that found in murine lung. Pelton et al showed that TGF- $\beta$ was present mainly in bronchial epithelial and smooth muscle cells in frozen samples from mouse lung ${ }^{10}$ but, in contrast to our study, they also found TGF- $\beta$ in fibroblasts. This difference between rodent and human lung fibroblasts was previously reported in cell culture experiments. ${ }^{16}$ Moreover, the expression of TGF- $\beta$ in fibroblasts may vary depending on various local stimuli. ${ }^{17}$

Whether the TGF- $\beta$ we detected in the normal human lung is active remains to be determined. In fact, TGF- $\beta$ from human bronchoalveolar lavage fluid requires acid activation to display biological activity, ${ }^{3}$ meaning that an in situ regulation of TGF- $\beta$ bioactivity is likely to occur after secretion.

TGF- $\beta$ is a pleiotropic cytokine with various immunological properties which are potentially relevant to lung physiology. Some of these are immunosuppressive, imbalanced by other effects on immune cell differentiation. TGF- $\beta$ inhibits the macrophage cytoxicity and monocyte synthesis of cytokines, but it respects the macrophage capacity of phagocytosis. It downregulates the proliferation of lymphocytes and limits their responses to cytokines. ${ }^{18-24}$ One can therefore speculate that TGF- $\beta$ in distal airways might allow macrophages to clear patho- 
gens without inducing unwarranted immune reactions and excessive lymphocyte activation. In addition, as it favours a Thl cytokine secretion profile, ${ }^{25}$ TGF- $\beta$ could prevent pulmonary hypersensitivity reactions. ${ }^{26}$ By stimulating maturation of $\mathrm{T}$ lymphocytes into memory cells $^{27}$ it could regulate the phenotype and function of pulmonary resting $\mathrm{T}$ cells. ${ }^{28}$ Also, by triggering $\mathrm{B}$ cell differentiation into IgA-producing cells ${ }^{29}$ TGF- $\beta$ could contribute to the IgA-mediated local response. ${ }^{30}$

Other properties of TGF- $\beta$ concern tissue homeostasis and repair and are also potentially relevant in the lung. TGF- $\beta$ strongly inhibits epithelial cell proliferation in vitro. It stimulates squamous differentiation of bronchial epithelial cells, ${ }^{31}$ and also triggers the expression of extracellular matrix components in various kinds of cells including pulmonary fibroblasts. ${ }^{67}$ Thus, TGF- $\beta$ probably contributes to the maintenance of the lung architecture and the regulation of local repair processes.

This descriptive study in the normal human lung provides new insights into the pulmonary cytokine network. By showing the presence of large amounts of TGF- $\beta$ in association with human bronchial epithelial cells it emphasises the potential local role of this cytokine in the regulation of pulmonary immunity and architecture. Further studies are necessary definitely to identify the cells that produce TGF- $\beta$, and to confirm the biological relevance of this cytokine to lung homeostasis.

The authors acknowledge M A Petit for the gift of the monoclonal antibody F 3525, M C Crevon for technical assistance, and $M$ Humbert for helpful discussions.

This work was supported by the Association Française pour la Lutte contre la Mucoviscidose, by the Association Claude Bernard, and by the Universite Paris-Sud.

1 Shull MM, Ormsby I, Kier AB, Pawlowski S, Diebold RJ, Yin $M$, et al. Targeted disruption of the mouse transforming growth factor- $\beta 1$ gene results in multifocal inflammatory disease. Nature 1992;359:693-9.

2 Kulkarni AB, Huh CG, Becker D, Geiser A, Lyght $M$, Flanders $\mathrm{KC}$, et al. Transforming growth fact $\beta_{\text {, null }}$ mutation in mice causes excessive inflammatory response mutation in mice causes excessive inflammatory respon

3 Yamauchi K, Martinet Y, Basset P, Fells GA, Crystal RG. High levels of transforming growth factor- $\beta$ are present in the epithelial lining fluid of the normal human lower respiratory tract. Am Rev Respir Dis 1988;137:1360-3.

4 Assoian RK, Fleurdelys BE, Stevenson HC, Miller PJ, Madtes DK, Raines EW, et al. Expression and secretion of transforming growth factor- $\beta$ by activated human macrophages. Proc Natl Acad Sci USA 1987;84:6020-4.

5 Adolff CH, Golden JA, Kennedy PW, Goetzl EJ, Turck $\mathrm{CW}$. Polymerase chain reaction amplification of messages for growth factors in cells from human bronchoalveolar lavage fluids. Inflammation 1991;15:259-68.

6 Pelton RW, Moses HL. The beta-type transforming growth factor: mediation of cell regulation in the lung. Am Rev Respir Dis 1990;142:S31-S35.

7 Border WA, Ruoslahti E. Transforming growth factor- $\beta$ in disease: the dark side of tissue repair. $\mathcal{f}$ Clin Invest 1992;90:1-7.

8 Sacco O, Romberger D, Rizzino A, Beckmann JD, Rennard SI, Spurzem JR. Spontaneous production of transforming growth factor- $\beta_{2}$ by primary cultures of bronchial epithegrowth factor- $\beta_{2}$ by primary cultures of bronchial epithe-
lial cells. Effects on cell behaviour in vitro. $\mathcal{f}$ Clin Invest 1992;90:1379-85.
9 Gibbons GH, Pratt RE, Dzau VJ. Vascular smooth muscle cell hypertrophy vs. hyperplasia: autocrine transforming growth factor- $\beta$ expression determinates growth response growth factor- $\beta_{1}$ expression determinates growth

10 Pelton RW, Johnson MD, Perkett EA, Gold LI, Moses HI Expression of transforming growth factor $-\beta_{1},-\beta_{2},-\beta$ mRNA and protein in the murine lung. Am $\mathcal{F}$ Respir Cell Mol Biol 1991;5:522-30.

11 Botney M, Parks WC, Crouch EC, Stenmark K, Mecham RP. Transforming growth factor- $\beta$, is decreased in remodeling bovine pulmonary arteries. I Clin Invest 1992;89:1629-35.

12 Majeski MW, Lindner V, Twardzik DR, Schwartz SM Reidy MA. Production of transforming growth factor- $\beta$ during repair of arterial injury. $\mathcal{J}$ Clin Invest $1991 ; 88: 904$ during.

13 Massague J. Receptors of the TGF- $\beta$ family. Cell 1992;69:1067-70.

14 Khalil N, O'Connor RN, Unruh HW, Warren PW, Flanders $\mathrm{KC}, \mathrm{Kemp} \mathrm{A}$, et al. Increased production and immunohisochemical location of transforming growth factor- $\beta$ in idiopathic pulmonary fibrosis. Am $\mathcal{f}$ Respir Cell Mol Biol 1991;5:155-62.

15 Broekelmann TJ, Limper AH, Colby TV, McDonald JA Transforming growth factor $\beta$ is present at sites of extracellular matrix gene expression in human pulmonary fibrosis. Proc Natl Acad Sci USA 1991;88:6642-6.

16 Kelley J, Fabisiak JP, Hawes K, Absher M. Cytokine signaling in lung: transforming growth factor- $\beta$ secretion by lung fibroblasts. Am $\mathcal{F}$ Physiol (Lung Cell Mol Physiol 4) 1991 260:L123-8.

17 Kelley J, Shull S, Walsh JJ, Cutroneo KR, Absher M. Autoinduction of transforming growth factor $\beta$ in human lung induction of transforming growth factor- $\beta$ in human lung
fibroblasts. Am $\mathcal{F}$ Respir Cell Mol Biol 1993;8:417-24.

18 Oswald IP, Gazinelli RT, Sher A, James SL. IL-10 synergizes with IL-4 and transforming growth factor- $\beta$ to inhibit macrophage cytotoxic activity. F Immunol 1992 148:3578-82.

19 Nelson BJ, Ralph P, Green SJ, Nacy CA. Differentia susceptibility of activated macrophage cytotoxic effector reactions to the suppressive effects of transforming growth factor- $\beta$. . I Immunol 1991;146:1849-57.

20 Musso $T$, Espinosa-Delgado I, Pulkki K, Gusella GL Longo DL, Vareso L. Transforming growth factor- $\beta$ downregulates interleukin-1 (IL-1)-induced IL-6 production by human monocytes. Blood 1990;76:2466-9.

21 Dubois CM, Ruscetti FW, Palaszynski EW, Falk LA Oppenheim JJ, and Keller JR. Transforming growth factor- $\beta$ is a potent inhibitor of interleukin-1 (IL-1) receptor expression. F Exp Med 1990;72:737-44.

22 Tsunawaki S, Sporn M, Ding A, Nathan C. Deactivation of macrophages by transforming growth factor $-\beta$. Nature 1988;334:260-2.

23 Turner M, Chantry D, Katsikis P, Berger A, Brenmann FM, Felman $M$. Induction of the interleukin-1 receptor antag onist protein by transforming growth factor- $\beta$. Eur $\mathcal{f}$ Immunol 1991;21:1635-9.

24 Kehrl JH, Roberts AB, Wakefield LM, Jakolew S, Sporn $\mathrm{MB}$, Fauci AS. Transforming growth factor $\beta$ is an important immunomodulatory protein for human B lymphocytes. $\mathcal{F}$ Immunol 1986;137:3855-60.

25 Fargeas C, Wu CY, Nakajima T, Cox D, Nutman $T$, Delespesse G. Differential effects of transforming growth factor- $\beta$ on the synthesis of Th-1 and Th-2-like lymphokines by human T lymphocytes. Eur f Immunol 1992; kines by hum

26 Meade R, Askenase PW, Geba GP, Neddermann K, Jacoby RO, Pasternak RD. Transforming growth factor- $\beta_{1}$ in hibits murine immediate and delayed type hypersensitivity. F Immunol 1992;149:521-8.

27 Swain SL, Huston G, Tonkonogy S, Weinberg A. Transforming growth factor $\beta$ and IL- 4 cause helper T cells precursors to develop into distinct effector helper cells that differ in lymphokine secretion pattern and cell surface phenotype. F Immunol 1991;147:2991-3000.

28 Saltini C, Richaldi L, Holroyd KJ, du Bois RM, Crystal RG. Lymphocytes. In: Crystal RG, West JB, eds. Lymphocytes in the lung: scientific foundations. New York: Raven Press, 1991:459-81.

29 Van Vlasselaer P, Punnonen J, de Vries JE. Transforming growth factor- $\beta$ directs IgA switching in human B cells. $\mathcal{J}$ Immunol 1992;148:2062-7.

30 Daniele RP. Immunoglobulin secretion in the airways. Annu Rev Physiol 1990;52:177-95.

31 Masui T, Wakefield LM, Lechner JF, LaVaeck MA, Sporn $\mathrm{MB}$, Harris CC. Type $\beta$ transforming growth factor is the primary differentiation-inducing serum factor for normal primary differentiation-inducing serum factor for normal
human bronchial epithelial cells. Proc Natl Acad Sci USA 1986;83:2438-42. 